\section{Tradição, memória e arquivo da brasilidade: sobre o inconsciente em Mário de Andrade*}

\section{Tradition, memory and archives of 'brazilianness': the unconscious in Mário de Andrade}

\section{Joel Birman}

Professor titular do Instituto de Psicologia / Universidade Federal do Rio de Janeiro; professor adjunto do Instituto de Medicina Social/ Universidade do Estado do Rio de Janeiro; pesquisador do Conselho Nacional de Pesquisa; diretor de Estudos em Ciências Humanas/Universidade Paris VII Rua Marquês de São Vicente, 250 22451-040 - Rio de Janeiro - RJ - Brasil joel.birman@pq.cnpq.br

Recebido para publicação em novembro de 2007. Aprovado para publicação em maio 2007.
BIRMAN, Joel. Tradição, memória e arquivo da brasilidade: sobre o inconsciente em Mário de Andrade. História, Ciências, Saúde - Manguinhos, Rio de Janeiro, v.16, n.1, jan.-mar. 2009, p.195-216.

\section{Resumo}

Circunscreve os conceitos de arquivo, memória e tradição na obra de Mário de Andrade, destacando nela as referências teóricas fundamentais ao conceito de inconsciente no discurso psicanalítico de Freud.

Palavras-chave: tradição; memória; arquivo; Mário de Andrade (1893-1945).

\section{Abstract}

The article analyzes the concepts of archive, memory and tradition in the work of Mário de Andrade, highlighting the fundamental theoretical references to the concept of the unconscious in Freud's psychoanalytical discourse.

Keywords: tradition; memory; archive; Mário de Andrade (1893-1945). 


\section{A problemática}

$\mathrm{M}$

ário de Andrade faleceu bastante jovem, não tendo ainda completado 58 anos.

Morreu precocemente não apenas para os nossos parâmetros atuais de longevidade, mas também para os de seu tempo e, principalmente, para os que pertenciam à sua classe social. Não obstante, produziu uma obra de grande extensão e amplitude, que nos foi legada como um patrimônio efetivo da cultura brasileira e que ainda nos incita na atualidade. Em decorrência disso, imortalizou-se pela sua vasta e múltipla produção intelectual, entre a qual se incluem as escritas em prosa e verso, assim como uma ampla e diversificada produção no registro da crítica e do ensaio. Além de seus escritos sobre a literatura, a música e as artes plásticas, com efeito devem-se destacar também as suas crônicas publicadas em jornais, nas quais a experiência social brasileira do dia-a-dia era não apenas devidamente registrada, mas também delineada com comentários sempre instigantes.

A esse respeito, suas crônicas são perpassadas por pontuações e escansões fulgurantes sobre o que ocorria na nossa cotidianidade, promovendo assim um encantamento do que se registrava apenas como fait divers nas demais páginas dos jornais. Pela mediação desses comentários brilhantes, a materialidade bruta da informação era transformada num esboço interpretativo sobre o 'imaginário' da brasilidade (Jardim de Moraes, 1978). Com essa iluminação e colorido, o suposto 'fato' assumia sempre a grandeza de um verdadeiro 'acontecimento', assumindo então a densidade e a pregnância de uma marca indelével de nossa tradição. Pode-se depreender disso, portanto, que com os poucos fragmentos dispersos de que dispunha Mário de Andrade realizava um esforço hercúleo para constituir uma 'cartografia' da memória brasileira.

Assim, essa cartografia estava já então em marcha, e de maneira original. As escritas críticas e literárias de Mário de Andrade foram constituintes daquela, pelos gestos retóricos e pelas virgulações que imprimiu nos documentos e objetos que não apenas reuniu, mas também compilou e forjou no seu trabalho contínuo sobre a experiência social brasileira. Esta se inscrevia tanto no registro do passado quanto do presente. Foi a dimensão imaginária dessa experiência que Mário de Andrade começou a configurar com paixão. Pôde então destacar como as marcas particulares da 'memória' brasileira foram conjugadas num 'estilo' que delineia a sua 'singularidade'. Seria justamente isso que se precipitaria como signo, numa modalidade específica de existência e de gestualidade sociais.

Portanto, o que existiria de singular no estilo da brasilidade estaria marcado na 'sintaxe' que conjugaria esses diversos signos e assim se destacaria e transformaria num emblema eloqüente daquela. Com isso, o próprio trabalho inerente 'da' memória brasileira, que se realizaria num processo contínuo de transmissão e apropriação estabelecida entre diversas gerações, se conjugaria com o trabalho do intérprete 'sobre' a memória, que delinearia a sua cartografia. Coloca-se então em evidência, enfim, a dimensão de 'ficção' que seria efetivamente constituinte da memória, de forma a costurar as marcas indeléveis do passado aos imperativos inadiáveis do presente, com vistas a um futuro possível que se pretendia assim forjar.

Dessa maneira, o trabalho intelectual de Mário de Andrade foi o de transformar a memória brasileira num 'arquivo' propriamente dito, para me valer de um conceito fundamental oriundo do discurso da história. Entretanto, na inflexão teórica desse conceito, 
que assumo aqui de forma deliberada e intencional, enuncio logo de saída que estou marcado na leitura dele pelas interpretações realizadas tanto por Foucault, em $A$ arqueologia do saber (1969), quanto por Derrida, em Mal de arquivo (1995). Isso porque, nas diferentes interpretações forjadas por esses autores (Derrida, Foucault, 2001), o conceito de arquivo seria também fundante de outro conceito, mais abrangente, qual seja, o de 'tradição'.

Portanto, se o conceito de tradição marcaria a emergência e a produção de uma dada cultura, assim como regularia suas reprodução e transmissão, numa escala temporal dimensionada pela história da 'longa duração' (Braudel, 1969), seria ainda a mesma tradição que poderia ser refigurada a partir dos imperativos da atualidade. No entanto tais imperativos se regulariam inevitavelmente pela antecipação do futuro, de maneira a entreabrir e delinear o horizonte de outras possibilidades para a tradição em pauta, com vistas à sua renovação e à afirmação de sua potencialidade efetiva.

Digo tudo isso no sentido ao mesmo tempo teórico e metodológico, para enunciar que na leitura que Mário de Andrade pretendeu realizar do imaginário brasileiro, transformando a nossa memória fragmentária e dispersa num arquivo propriamente dito, o que estava inequivocamente em pauta era o desejo de esculpir os fundamentos da tradição brasileira. Para explicitar tais fundamentos, necessário seria configurá-los pela mediação de diversas materialidades discursivas. Estaria aqui a 'problemática' crucial que pautou o percurso intelectual de Mário de Andrade, nas diferentes retóricas que empreendeu com mestria, seja no registro poético ou no ensaístico. Com efeito, se a compilação documental do passado brasileiro foi crucial no seu percurso intelectual, pretendendo realizar assim uma cartografia rigorosamente documentada da nossa memória, sem dúvida os imperativos políticos do presente e a antecipação do futuro seriam inseparáveis de seus propósitos teórico, ético e estético. Seria a brasilidade como tradição, enfim, a problemática fundamental da ampla pesquisa empreendida por Mário de Andrade.

Por isso mesmo, alguns críticos literários - como Dantas Mota, Wilson Martins, João Etienne Filho e Naief Sáfady - puderam dizer que, se Mário de Andrade não foi o nosso maior poeta, foi certamente o mais completo, por ter realizado não apenas o verso rigorosamente metrificado e rimado, mas também o mais livre. Antecipou-se assim à poética social e à poesia participante, numa prática eminentemente erudita. Pôde transformar então o discurso estabelecido e existente sobre o folclore (Etienne Filho, 1980, p.1), por imprimir em sua leitura um olhar ao mesmo tempo antropológico e psicanalítico. Pode-se dizer que Mário de Andrade deslocou-se progressivamente do registro estritamente literário poético para o da construção crítica do arquivo do Brasil, configurando então o seu percurso a morte do poeta (Jardim de Moraes, 2005). De qualquer maneira, é a brasilidade como tradição, configurada pelas diferentes coordenadas do arquivo e enunciada em diversas materialidades discursivas, o que faz a sua emergência, na retórica de Mário de Andrade, de maneira eloqüente e fulgurante.

Portanto minha questão fundamental, neste artigo, será a de enfatizar as relações existentes entre os registros da história, da tradição e do arquivo em Mário de Andrade, indicando a presença efetiva do discurso freudiano no seu pensamento. A metáfora e o conceito de 'assombração', por ele enunciada na crônica "Memória e assombração", publicada em maio de 1929 (Andrade, 2005b, p.82-83), oferece-me uma pista teórica segura, na qual a dicção e a flexão retóricas remetem inequivocamente ao discurso psicanalítico. 
Vou-me valer também do discurso teórico de Benjamin, além dos de Foucault e Derrida, sobre arquivo e modernidade, para me embrenhar na trama discursiva de Mário de Andrade e esboçar assim a sua leitura modernista da tradição brasileira. Enfim, o conceito de 'recepção' desenvolvido por Jauss, no campo da estética da recepção, também me orientará.

\section{Política e história}

Vou começar este percurso, em Mário de Andrade, pela alusão aos discursos sobre a 'política' e a 'história' realizados por Maquiavel, uma vez que, para ele, a emergência histórica de cada uma dessas modalidades de discursividade implicava necessariamente a outra. Vale dizer, a constituição teórica do discurso da filosofia política com Maquiavel, no Renascimento, desdobrou-se em outra concepção sobre o discurso da história. Com isso, uma nova relação entre passado, presente e futuro foi então constituída, numa operação teórica que implicou uma 'descontinuidade' radical em face da Antiguidade e da Idade Média. Se nestas, com efeito, era o tempo do 'passado' que era transformado em emblema e ideal que deveriam pautar a existência humana no tempo do 'presente', desde Maquiavel era a relação do presente com o 'futuro' que seria decisiva na reflexão sobre a política e a história. Não se tratava mais de olhar para as vidas exemplares do 'passado', como realizava Plutarco em Vidas paralelas (2001), e para a leitura ideal sobre o melhor regime político (Strauss, 1986, 1987); o que estava em questão agora seria uma nova relação, 'estratégica' e 'tática', do presente com o futuro, de maneira que o tempo do passado seria aquilatado em decorrência dos imperativos da 'atualidade', nos campos social e político.

Assim, no seu Discurso sobre a primeira década de Tito Lívio (Machiavel, 1952a), escrito entre 1513 e 1520, Maquiavel pretendeu realizar a leitura da constituição da República de Roma com vistas a empreender a construção da República de Florença. Era a condição de governabilidade desta última que estava em questão, no tempo presente. Isso porque, ocupando a posição de secretário de Estado em Florença durante alguns poucos anos, Maquiavel voltou-se posteriormente para a reflexão teórica sobre a República de Roma, tanto para pensar naquilo que fora forjado no passado como República quanto para examinar as possíveis transposições e os seus impasses para conceber devidamente as coordenadas da então recente República florentina.

Na nova perspectiva teórica estabelecida então por Maquiavel, o que ocorrera no passado não deveria ser algo a ser conhecido para ser reproduzido literalmente no presente, que estaria longínquo na ordem do tempo e da história, mas, ao contrário, deveria ser fundamentalmente objeto de 'meditação' para o leitor e o político. Dessa maneira, poderíamos aprender algo com o passado articulando-o criticamente com o presente, de forma a conferir viço e sentido ao que nos acontece na atualidade.

Seria portanto por essa nova postura, ao mesmo tempo teórica e prática, que Maquiavel teria passado a atribuir outra relação estratégica e tática entre passado, presente e futuro, de maneira a refundar as concepções sobre a política e a história. Isso porque, na concepção original de 'governabilidade' concebida por Maquiável em O príncipe (1952b), escrito em 1513, a figura do governante se deveria orientar agora pela 'Virtude' e não mais pela 'Fortuna'. Tal interpretação pressupunha outra leitura da história, pois o curso dessa não 
seria mais definido pelos imperativos divinos e de forma 'circular', mas sim pelos desígnios dos homens, numa luta permanente entre os diversos oponentes presentes na cena política. Por isso mesmo o novo príncipe deveria ser agora guiado pela Virtude e não mais pela Fortuna, pois teria que agir a partir de escolhas realizadas num contexto social permeado pelos conflitos entre os oponentes, fazendo escolhas e delineando direções marcadas pelos sentidos estratégico e tático. Em decorrência, suas ações virtuosas seriam produtoras efetivas de história, pois a dimensão da imprevisibilidade marcaria as relações humanas, uma vez que a 'providência' não garantiria mais a previsibilidade circular da ordem do mundo.

Nessa perspectiva Maquiavel não foi apenas o fundador do moderno discurso sobre a política, como nos ensina a história da filosofia política (Berns, 2000; Lefort, 1972; Skinner, 1981; Voegelin, 2000), mas também do discurso moderno da história, já que as escolhas e ações do príncipe forjariam a própria historicidade dos acontecimentos na ordem da experiência temporal. Os discursos da política e da história passaram a conjugar-se de maneira orgânica desde então, pois seria a nova ordem da imprevisibilidade dos acontecimentos, num 'universo' que começara a se delinear como infinito, que provocaria ruptura e desconti-nuidade com a concepção do 'cosmo' finito e circular da Antiguidade e da Idade Média (Koyré, 1973), que começara então lentamente a caducar.

Por isso mesmo, a apropriação meditativa e crítica da memória da República de Roma, em contraste com a oposição reprodutiva da memória, seria constitutiva tanto do discurso da política quanto do discurso da história. Porém se Maquiavel se inscreveu num momento crucial da construção da Itália e da Europa no Renascimento, época marcada por uma ruptura significativa com o tempo do passado, pode-se dizer também que Mário de Andrade situa-se num momento crucial de descontinuidade da história no Brasil.

\section{Modernismo e descontinuidade}

Não quero dizer, com tudo isso, que Mário de Andrade tenha sido um leitor sistemático de Maquiavel, tampouco que tenha feito comentários eruditos a seu respeito, mas sim que foi marcado por esse solo fundador de uma nova conjunção entre política e história, que delineou seu percurso teórico. Por isso mesmo pôde enunciar, quase no final de seu "Prefácio interessantíssimo" à Paulicéia desvairada, de 1921, que "o passado é lição para se meditar, não para reproduzir" (Andrade, 1980a, p.29). É claro que Mário de Andrade se refere ao campo da criação artística, isto é, às histórias da literatura, da música e das artes plásticas, e não ao registro da política no sentido estrito. No entanto é a mesma flexão teórica realizada por Maquiavel que está em questão, inscrita agora no registro da estética e numa reflexão aguda sobre a tradição. Além disso, como ainda se verá adiante, é pelo viés da política que a dimensão do comando, constituinte da concepção de arquivo, encontra o seu solo fundador.

Como se sabe, Mário de Andrade não foi propriamente um político, no sentido estrito do termo, mas ocupou cargos públicos importantes no Ministério da Educação, dirigido então por Capanema, e posteriormente na Secretaria da Cultura do Estado de São Paulo. Portanto realizou a prática política no campo da cultura e delineou escolhas e ações governamentais nesse campo específico. Essa ocupação governamental por certo marcou 
os anos finais de sua vida intelectual de maneira indelével, definindo sua escrita literária e sua produção teórica como ensaísta.

Nesse contexto histórico Mário de Andrade realizou sua reflexão crítica sobre o movimento modernista no Brasil, que teria provocado efetiva descontinuidade na experiência social brasileira. Numa leitura retrospectiva sobre o percurso intelectual de Mário de Andrade, pode-se afirmar que foi essa descontinuidade histórica que demarcou decisivamente o seu percurso, cuja problemática também definiu.

Refiro-me, aqui, às meditações crítica e retrospectiva sobre o modernismo, escritas em 1941, em dois ensaios cruciais, "O movimento modernista" (Andrade, 2002a) e "A elegia de abril" (Andrade, 2002b). Ambos foram publicados logo depois, em 1943, numa coletânea de ensaios intitulada Aspectos da literatura brasileira. O que nos disse Mário de Andrade nessa releitura tardia sobre o modernismo brasileiro? Como situava a descontinuidade histórica que esse produzira?

O modernismo seria não apenas a reivindicação permanente do direito à pesquisa estética e a atualização da inteligência brasileira, mas também a estabilização de uma consciência criadora nacional (Andrade, 2002a). Cada um desses traços já se encontrava presente na história pré-moderna da arte no Brasil; o que teria caracterizado o ideário do modernismo foi a articulação efetiva dessas três exigências numa totalidade orgânica, de maneira a constituir uma nova consciência coletiva sobre as questões estéticas. Estaria justamente aqui a significação histórica da descontinuidade empreendida pelo modernismo.

O modernismo brasileiro se inscrevia assim num campo mais amplo, qual seja, o do debate entre os antigos e os modernos, que provocara já uma ruptura na tradição européia nos séculos XVII e XVIII e produzia igualmente, mas de maneira tardia, uma descontinuidade radical no imaginário social e estético brasileiro (Andrade, 2002a). Assim, se os antigos pretendiam sempre reproduzir os textos de seus antepassados, numa epopéia repetida que era forjada como pequenas variações sobre os mesmos temas, os modernos pretendiam constituir, em contrapartida, uma partitura que fosse nova e original (Dejean, 1997; Lecoq, 2001). Vale dizer, a querela entre os antigos e os modernos representava, num registro especificamente estético, aquilo que foi realizado por Maquiavel na conjunção entre a política e a história. Com isso o novo teria que ser permanentemente inventado em outra historicidade e temporalidade, num registro estrito da linguagem. Enfim, o que se produziria de novo, isto é, a descontinuidade produzida no registro da arte teria então as suas conjunções com a consciência coletiva do Brasil na modernidade.

É apenas nesse contexto que a formulação de Mário de Andrade, no prefácio da Paulicéia desvairada, ganha todo o seu peso e densidade, pois, ao afirmar que "o passado é lição para meditar, não para reproduzir" (Andrade, 1980a, p.29), o movimento modernista assumia sua condição eminentemente moderna. Isso porque empreendeu efetivamente a ruptura com os antigos, no registro estrito da história brasileira. Enfim, a descontinuidade assim se estabeleceu, inaugurando outro percurso no imaginário brasileiro.

No entanto essa 'postura' modernista não deveria ficar restrita ao campo especificamente estético, fosse o da literatura, o das artes plásticas, o da música ou o do teatro, mas se inscrever também em outros registros do imaginário e da consciência social brasileiros. Por isso mesmo, numa de suas crônicas publicadas no Diário Nacional, em 1929, Mário de 
Andrade evocou Graça Aranha, assim como o fez no ensaio "O movimento modernista". Neste, com efeito, afirmava que a nova postura modernista não deveria ficar restrita ao campo estritamente estético, mas se disseminar amplamente entre outros campos e registros sociais da brasilidade (Andrade, 2002a), para relançá-la em outros percursos.

Para que isso pudesse realizar-se, contudo, a intelectualidade brasileira precisaria empreender efetivamente uma ruptura significativa com a tradição européia, na qual estaria permanentemente se espelhando. Ou seja, o intelectual brasileiro estaria sempre escrevendo com o olhar voltado para a Europa e esquecia assim o que estaria ocorrendo no Brasil (Andrade, 2002a), e era essa postura, eminentemente pré-modernista, que assumiria forma e corpo naquilo que Mário de Andrade denominava "moléstia de Nabuco", referindo-se à saudade que Joaquim Nabuco sentia da Europa quando estava no Brasil e à saudade do nosso país quando estava na Europa.

Nesse contexto, a atmosfera reinante no campo intelectual brasileiro era eminentemente enfadonha, marcada que era pela mesquinharia, pela qual pequenas intrigas e maledicências sobre os outros delineavam infalivelmente as coordenadas desse campo intelectual. A lavagem da roupa suja em público, com efeito, definia de maneira vulgar o estilo desse campo intelectual, como afirmara Mário de Andrade em outra crônica publicada do Diário Nacional (Andrade, 2005a). Para reconfigurar efetivamente o campo intelectual em outra direção, entreaberta pelo modernismo, articulando intimamente arte e experiência social, necessário seria forjar outra 'concepção da arte', que a afastasse definitivamente de uma perspectiva pré-moderna e que a inscrevesse agora em outra consciência coletiva.

\section{Despertar e descobrimento}

No ensaio "O artista e o artesão", sua aula inaugural para os cursos de filosofia e história da arte da Universidade do Distrito Federal, em 1938, publicado posteriormente no livro $O$ baile das quatro artes, Mário de Andrade realizou a crítica sistemática da arte 'individualista' e 'contemplativa', postulando a importância da arte como 'fazer' (Andrade, 1975). A historiadora Margarida de Souza Neves (1998, p.4) considera esse ensaio o 'testamento' estético do autor.

Assim, enquanto a arte individualista e contemplativa seria esteticista, pelo culto que realizaria da estética em si própria e pela promoção da arte pela arte, a arte como fazer suporia uma prática efetiva de trabalho, que teria na figura do artesão seu modelo e paradigma (Andrade, 1975). Se o esteticismo, que impregnaria a primeira, se desdobraria numa limitação estilística, na arte como fazer, em contrapartida, estaria em pauta um projeto 'messiânico', no qual a transformação do mundo estaria assim necessariamente enunciada (Andrade, 1975). Portanto, se a contemplação estetizante se desdobraria numa imaginação evidentemente onipotente, o fazer artesanal se evidenciaria por uma mudança da materialidade do mundo visando à sua transformação messiânica. Além disso, na artesania se condensa a tradição de um métier e pressupõe-se a idéia de 'trabalho', não sendo então a arte a ocupação de elites desocupadas, que se podem dar ao luxo onipotente de viver para contemplar o mundo. Daí porque a própria trajetória intelectual de Mário de Andrade fundou-se no deslocamento da primeira concepção para a segunda, na qual arte 
como fazer e artesania implicaria um compromisso ético e político com a brasilidade razão pela qual, me parece, Mário de Andrade passou efetivamente a assumir cargos públicos no campo da cultura, tanto no governo federal quanto no estado de São Paulo.

Seria então pela concepção da arte como fazer que o artista poderia comprometer-se com os destinos da nação e da nacionalidade, ao articular-se organicamente com o projeto de constituir uma efetiva tradição brasileira. Seria por esse viés, portanto, que as consciências estética e social se conjugariam em novo projeto e consciência coletivos, com vistas a forjar a especificidade da tradição brasileira. Apenas nessa perspectiva poderíamos efetivamente 'despertar', pois a nova consciência social seria a condição de possibilidade para que pudéssemos sair de nosso 'adormecimento' secular em relação à nossa memória e começar a realizar um efetivo trabalho de arquivamento. Foi justamente isso que enunciou literalmente Mário de Andrade no poema intitulado "Descobrimento", publicado em 1927:

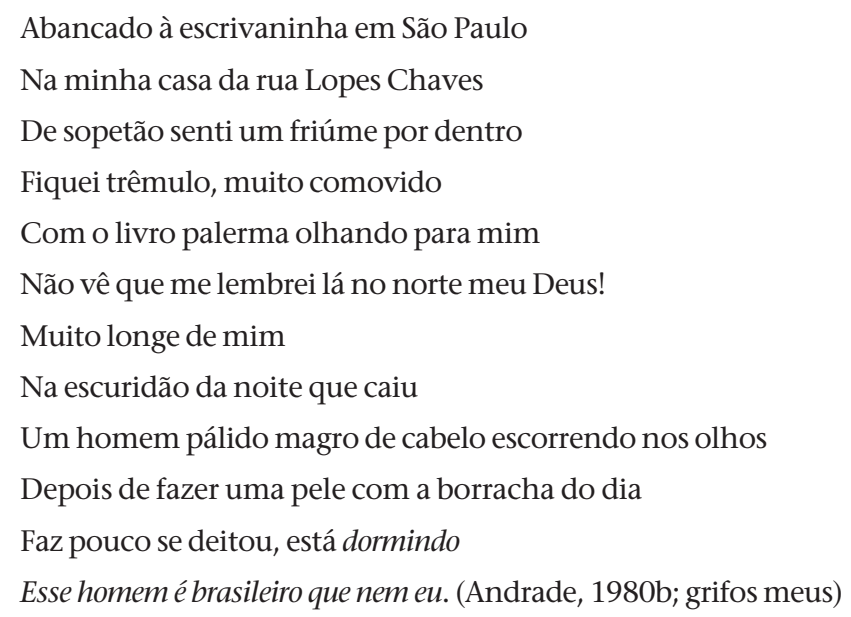

Seria então pelo despertar do brasileiro adormecido que seria possível constituir uma tradição propriamente dita, estabelecendo outro arquivo que instituísse uma nova relação com a nossa história. Portanto a problemática fundamental que começou a impor-se a Mário de Andrade, em outra relação com o passado e com o futuro, catalizado que foi pela experiência modernista como consciência crítica da brasilidade, seria a constituição de uma tradição eminentemente brasileira. Seria então 'tradição' a palavra e o conceito cruciais no discurso crítico de Mário de Andrade; como um fio de prumo, ela passou a orientar desde então o seu percurso intelectual.

\section{Presente, futuro e passado}

Assim, para constituir uma tradição brasileira propriamente dita não bastaria apenas cultuar o passado como tal e em si mesmo, reproduzi-lo na sua enfadonha mesmice, mas sim retomar criticamente suas coordenadas e linhas de força, e destacar então suas fraturas e seus impasses. A reconstrução da memória seria a condição 'necessária' para isso, mas não condição 'suficiente', não obstante a importância decisiva do trabalho reconstrutivo daquela. Outra relação com o passado e a memória se imporia, pela qual outra interlocução 
entre estes se realizaria: seria necessário refinar criticamente o passado e inscrevê-lo decisivamente no presente, com a finalidade de reencantar o presente com as trilhas e sulcos lastreados pelo passado, ou de sublinhar o que já existiria potencialmente, no passado, do presente, como esboço e linha de força, mas em estado virtual. A relação entre presente e passado teria assim mão dupla, não se restringindo à ação unívoca do segundo sobre o primeiro, num determinismo e evolucionismo teoricamente discutíveis.

Para tanto seria preciso considerar que o presente, como atualidade concreta e operante que é de uma dada tradição, se projeta no futuro como um ponto de chegada, tendo então finalidades a serem atingidas e conquistadas. A leitura do passado como memória pressupõe, portanto, a antecipação de futuro como possibilidade, a partir do campo da atualidade. A reconstrução do passado como memória da tradição implica necessariamente, enfim, o 'vir-a-ser' dessa mesma tradição, numa 'antecipação' do futuro pelo tempo verbal do futuro anterior.

Pode-se dizer, assim, que a postura crítica de Mário de Andrade em face da reconstrução da memória como tradição, que implica uma sintaxe precisa entre os registros do presente, do futuro e do passado, pressupõe a assunção de uma postura ética e política sobre brasilidade que se desdobra também numa estética. Sua crítica à concepção da arte individualista e contemplativa, assim como sua promoção da concepção da arte como fazer já evidenciava isso, no ensaio "O artista e o artesão", de 1938 (Andrade, 1975). É precisamente nesse sentido que concordo com a historiadora Margarida de Souza Neves (1998), quando afirma que esse ensaio condensa o testamento estético de Mário de Andrade (p.4), pois um testamento nada mais é que um projeto de futuro, isto é, uma antecipação realizada no presente de um possível vir-a-ser da tradição brasileira. Tudo isso evidencia, no entanto, que Mário de Andrade não assume a posição de realizar uma historia 'positivista' do passado brasileiro, que valorizaria o registro do 'fato' na sua suposta objetividade e que, como tal, devia ser rememorado na sua eloqüência. Com efeito, se a leitura dos registros do fato e da memória seria comandada pela atualidade e visaria antecipar o futuro como possibilidade de uma tradição, o que Mário de Andrade realizou efetivamente foi uma 'genealogia' no seu sentido estrito (Nietzsche, 1971; Foucault, 1994d). O que lhe interessa é a reconstrução do Brasil como tradição, na qual o trabalho de rememoração do passado histórico brasileiro seria apenas condição necessária para isso, mas não suficiente.

Com efeito, apesar do rigor com que empreendia as reconstruções do passado brasileiro, principalmente no que concerne à história da música brasileira (Andrade, 1999, 2006, 1991), e de sua preocupação em 'colecionar' objetos contemporâneos que se materializaram como signos da tradição brasileira - como esculturas, pinturas, textos literários e do cancioneiro popular -, a preocupação maior de Mário de Andrade foi a de fazer dialogar o passado com o presente, numa dupla direção de encantamento recíproco, o que pressupunha, é claro, a antecipação do futuro como destino possível da tradição brasileira. Certamente não é por acaso que na sua concepção da arte-fazer, enunciada no ensaio "O artista e o artesão" (Andrade, 1975), o que se destaca é a dimensão messiânica da arte como tradição, em que é o futuro que se projeta como antecipação do vir-a-ser, a partir das linhas de força que se delineariam na atualidade. 


\section{Refundar 0 arquivo}

Nessa perspectiva, Mário de Andrade queria conhecer e tomar posse simbolicamente do Brasil. Seria a sua maneira de despertar do secular adormecimento em face da tradição, desdobrando, assim, uma postura e um gesto simbólico eminentemente modernistas. Não pretendia com isso apenas conhecer o que era o passado significativo da brasilidade, mas também os seus confins e bordas esquecidos no presente, situados que estavam no vasto território continental brasileiro. Portanto seria através de suas viagens 'amadoras' como etnógrafo, como dizia, assumindo-se como um 'turista aprendiz' no seu próprio país (Andrade, 1976), que Mário de Andrade pretendia inscrever a memória do passado no presente vivo da brasilidade, para conferir então o sentido da tradição tanto ao passado quanto ao presente.

Como 'turista aprendiz' que esboçava as sendas desconhecidas e desmapeadas dos confins do Brasil, Mário de Andrade começou a realizar outra cartografia do espaço social brasileiro. Novas marcas e novos traçados passaram a ser inscritos na carta da brasilidade, modelando sulcos e reentrâncias até então inexistentes. Uma geografia outra do território brasileiro começou a tomar corpo e forma, constituindo volumes, planos e retas que não tinham sido ainda desenhados, pois era a geometria do imaginário que estava sendo forjada, pela qual a materialidade da tradição finalmente se evidenciava.

As viagens que realizou pelo Brasil foram iniciadas em 1925, com um grupo de amigos modernistas, entre os quais Oswald de Andrade, com a ida às cidades históricas de Minas Gerais. Mário de Andrade definiu essa viagem como a sua 'descoberta do Brasil'. Em seguida o seu percurso se fez sempre rumo ao Norte, buscando paisagens e modalidades outras de civilidade até então desconhecidas e pouco exploradas. Dessa maneira, a cartografia do imaginário brasileiro foi progressivamente se empreendendo pela reunião sistemática de materialidades simbólicas oriundas de diferentes formas de discursividade (música, texto, escultura, pintura), que se constituíram como 'acervo' daquele imaginário.

Podemos enunciar então que, com os novos mapeamentos e cartografias que empreendia do imaginário brasileiro, Mário de Andrade pretendia realizar a 'refundação' do arquivo brasileiro. Enuncio aqui 'refundação' e não 'fundação', pois o arquivo brasileiro existia anteriormente a esse empreendimento intelectual, é óbvio, nas diversas histórias já escritas sobre o Brasil. O que Mário de Andrade quis realizar foi uma reformatação do arquivo da brasilidade, nele introduzindo novos enunciados ontológicos e propondo um outro princípio nomológico.

Proponho inicialmente o conceito de arquivo em Derrida (1995), como mencionei, pois ele nos permite balizar o trabalho intelectual de Mário de Andrade de maneira diferente, ao nos indicar algumas pistas teóricas para que essa interpretação possa ser feita. Assim, se o passado não é algo para ser reproduzido mas sim meditado pelo intérprete situado no tempo presente, como nos disse o filósofo, o passado não é apenas memória. E se esta é, como um conjunto de impressões e inscrições, a condição necessária do arquivo, contudo não é condição suficiente, porque o arquivo supõe sempre o trabalho sobre a linguagem e o discurso, os quais delineiam inflexões e direções às inscrições presentes na memória. Esse trabalho da linguagem e do discurso se funda, é claro, na atualidade e antecipa, além disso, o futuro como possibilidade. Tal operação não se pode realizar no campo da memória, 
evidentemente, pois depende da relação viva do intérprete com as impressões e inscrições daquela. Seria assim por esse viés que o intérprete constituiria ainda novas impressões e inscrições, como realizou Mário de Andrade com os diversos acervos discursivos que constituiu, tanto pela mediação de seu gesto interpretativo quanto pela nova documentação que estabeleceu e com a pesquisa 'amadora' de etnografia que empreendeu, nas suas viagens pelo Brasil.

Se no registro 'horizontal' o arquivo se apresenta como um conjunto de enunciados que delineiam a sua dimensão ontológica, no registro 'vertical' o arquivo tem uma dimensão nomológica, que define 'a lei' que o ordena. Estaria então na verticalidade o 'comando' do arquivo. A pergunta é: 'quem' comanda o arquivo? (Derrida, 1995, p.11-17). Não há dúvida que seria por essa dimensão que o arquivo se articula necessariamente com o 'poder', que define tanto um 'lugar' para que os documentos sejam arquivados quanto o seu 'guardião'. É claro que o intérprete se inscreve necessariamente tanto nesse lugar de poder quanto na gestão da documentação, que é constituinte do arquivo. Assim, a participação de Mário de Andrade em órgãos dos governos federal e estadual de cultura, que definiam políticas para a administração desse campo, indica a presença do Estado, do qual Mário fazia parte, no comando do arquivo. É a concepção de cultura como patrimônio o que já se constitui aqui, no registro histórico.

Por outro viés interpretativo, Foucault (1969) destaca também a dimensão do poder na produção e na gestão do arquivo. Isso porque a leitura do arquivo não se restringe às dimensões semântica e lógica dos enunciados ontológicos nele presentes, mas supõe também a intervenção do poder pela mediação de códigos classificatórios e interpretativos. Dessa maneira, a constituição e a leitura dos arquivos seriam permeadas por 'jogos de verdade', para nos valermos de um conceito tardio enunciado por Foucault (1994e) no final do seu percurso. Seria pela mediação decisiva desses jogos de verdade que certas operações interpretativas, que estão presentes tanto na constituição quanto na leitura do arquivo, se realizam na dimensão ficcional, a qual se inscreve de fato e de direito na tessitura daquele. Com efeito, a ficção marcaria então a escolha da documentação, os recortes nela realizados e as linhas de força que delineiam a sua leitura, não existindo, assim, jamais o documento como puro fato, desenvolvido fora daquelas operações (Derrida, 1995).

Para inserir outra dimensão conceitual e complexificar um pouco mais a leitura que proponho, pode-se dizer com Jauss (1978) que a composição do arquivo e a sua interpretação seriam também marcadas pela dimensão da 'recepção'. Esse teórico alemão realizou o seu trabalho no campo da estética e da literatura, em que enunciou uma teoria da recepção, mas a mesma leitura pode ser feita quanto à constituição de outros arquivos. De qualquer forma, no que tange ao trabalho intelectual de Mário de Andrade, estava em pauta indubitavelmente a dimensão estética do arquivo, na qual pôde realizar a recepção de diferentes discursos teóricos na sua leitura sobre a brasilidade.

\section{Comando anticolonial}

Se os conceitos de arquivo, formulados por Derrida e Foucault, podem efetivamente contribuir para explicitar e esclarecer o que está em pauta na cartografia e na refundação 
do arquivo realizadas por Mário de Andrade, assim como o conceito de estética da recepção de Jausss, pode-se dar agora um passo a mais no que tange à dimensão do comando presente nesse trabalho de arquivamento.

Não resta dúvida de que Mário de Andrade assume uma posição ética e política diante da brasilidade e que ela se desdobra numa postura que é, no mínimo, rebelde e principalmente subversiva no que tange ao arquivo da brasilidade. Com efeito, sua postura é marcadamente 'anticolonialista', e esse pressuposto delineou a direção de sua leitura sobre a brasilidade. Seria nesses termos que ele buscou refundar o arquivo da brasilidade, realizando uma 'desconstrução' sistemática do arquivo existente (Derrida, 1967a), que se fundava num pressuposto colonialista, pelo enunciado de outro pressuposto. Este se enuncia pela metáfora recorrente da 'moléstia de Nabuco', que condensa a postura colonizada, presente em parcela significativa da intelectualidade brasileira, cujos olhos se mantêm sempre voltados para a Europa e não enxergam o que se passa no Brasil.

Além disso, esse mesmo pressuposto colonialista se condensaria ainda na concepção individualista da arte, que é estetizante de acordo com os cânones, sempre copiados e imitados, do que se prescreve na Europa. Nesses termos, realizar a leitura da arte como fazer implicaria uma crítica sistemática do pressuposto colonialista presente no imaginário brasileiro e a enunciação de outro pressuposto nomológico (Derrida, 1995). Recentrar o arquivo na idéia de brasilidade, enfim, implicaria efetivamente constituir outro comando.

Nessa perspectiva podemos aproximar o trabalho de refundação do arquivo da brasilidade de Mário de Andrade das reflexões de outro arquivista importante, que buscou fundar o arquivo da modernidade no Ocidente. Refiro-me a Walter Benjamin, que pretendeu fundar o arquivo da modernidade em toda a sua obra, mas que assumiu, com a pesquisa realizada nas Passagens (Benjamin, 2006), uma inflexão decisiva. A investigação que começou a realizar na Biblioteca Nacional de Paris, nos anos finais de sua vida, foi fundamental para isso, como se sabe. Foi nesse contexto histórico e teórico que Benjamin escreveu o seu último ensaio, publicado apenas após a sua morte por Hannah Arendt (Benjamin, 1991). Trata-se de "Sobre o conceito da história". Pode-se enfatizar, nesse ensaio magistral, pelo menos duas grandes teses que podemos aproximar da refundação do arquivo da brasilidade por Mário de Andrade. Antes de mais nada, a de que a história escrita e legitimada é sempre a história dos 'vencedores', que registram a memória dos fatos que contam e compõem o seu arquivo a partir da posição de quem vence, isto é, de quem domina e impõe a sua versão dos acontecimentos aos 'vencidos'. Essa documentação arquival passa necessariamente pela ficção dos vencedores, qual seja, de suas façanhas e conquistas. Os vencidos não têm história, pois os seus arquivos nem foram constituídos. Portanto a escritura histórica seria tão simples e trágica como isso. Vale dizer, para que os perdedores viessem a ter uma história, necessário seria que pudessem sair dessa posição dominada e se deslocar para a de vencedores. Somente assim poderiam constituir o seu arquivo a partir dos traços de sua memória e da imposição de outro comando nomológico.

Em seguida, Benjamin enfatiza, como desdobramento da tese anterior, a de que a concepção moderna e iluminista de 'progresso' não passa de uma ideologia - formulada pelos vencedores, é claro. Isso porque, se olharmos para trás e para o passado - como na 
pintura Angelus Novo, de Klee -, o que podemos constatar é que em cada passo dado em direção ao suposto progresso o que se realizou ao mesmo tempo foi um ato de 'barbárie', pelo qual os vencedores destituíram os perdedores e implantaram sua dominação política. Tal destituição passa necessariamente pelo apagamento da memória e pela impossibilidade de esta se inscrever como arquivo, enfim, e que estabelece o processo simbólico de dominação.

Essas teses de Benjamin sobre a filosofia da história devem muito teoricamente, como se sabe, ao ensaio de Nietzsche sobre a crítica do discurso da história (Gagnebim, 1994), realizada na segunda metade do século XIX. Nas suas Segundas considerações intempestivas, com efeito, Nietzsche (1988) empreendeu a crítica sistemática da história alemã realizando uma crítica contundente à idéia de 'origem' presente no discurso histórico e enfatizou, em contrapartida, as dimensões de interpretação e ficção que estariam necessariamente presentes nas reconstruções históricas. Nietzsche já caminhava na direção de forjar decisivamente a genealogia como saber, em oposição à história e ao historicismo.

Se retomarmos essas formulações de Benjamin na leitura do percurso teórico de Mário de Andrade, podemos dizer que, ao empreender a crítica do pressuposto colonialista presente no arquivo do Brasil, Mário desarticulou o princípio nomológico desse arquivo pela proposta de outro, voltado agora para o recentramento sobre o Brasil e não voltado para a Europa. Com isso, a voz dos vencidos poderia ganhar espaço e passaria a ser inscrita no arquivo da brasilidade, começando a desbancar assim a voz dos vencedores. Enfim, as viagens etnográficas de Mário de Andrade lhe possibilitaram os meios para dar voz aos vencidos e inscrevê-los então no arquivo da brasilidade. Além disso, ao dar voz aos vencidos, a dimensão de barbárie presente na leitura dos vencedores começou também a ser questionada, e pôde-se reconhecer não apenas a atrocidades dos dominadores mas também o que existe da civilidade no mundo dos dominados. As viagens sempre rumo ao Norte, realizadas por Mário de Andrade, rearticularam e refundaram o imaginário da brasilidade, e ele constitui, então, para esse imaginário, outro arquivo.

Pode-se dizer, portanto, que a pesquisa teórica de Mário de Andrade não era a de um colecionador do Brasil e tampouco a de um folclorista. Pelo contrário, ele pretendia forjar outro arquivo da brasilidade, refundando-o pela desconstrução do arquivo instituído, não apenas ao inscrever neste novos enunciados ontológicos, mas principalmente ao proporlhe outro princípio nomológico de comando. Recentrando-se agora no pressuposto anticolonialista do comando e criticando o antigo pressuposto colonialista, Mário de Andrade participava de um novo projeto nacional popular para repensar o Brasil a partir da atualidade e com vistas ao seu futuro como nação.

A constituição da problemática dos discursos sobre o patrimônio nacional, com Rodrigo de Melo Franco, foi o desdobramento desse projeto no plano político e do Estado. Para isso seria necessário pensar o Brasil como uma 'totalidade orgânica', isto é, como uma 'nação' propriamente dita e não mais restrita a certos estados e regiões. Para que se constituísse uma leitura 'universalista' e não mais 'particularista' sobre a brasilidade, seria fundamental superar os regionalismos e o seu correlato, qual seja, o discurso do folclore. Apenas assim a tradição brasileira se poderia efetivamente constituir. 
Joel Birman

\section{Da voz à escrita}

Por isso mesmo, Mário de Andrade empenhou-se em conceber a existência de uma 'língua brasileira', enunciando que essa não se restringiria às coordenadas da 'língua portuguesa'. Assim, formulava que, no Brasil, falamos o 'brasileiro', com formas, inflexões e acentos singulares. Existiria assim uma decalagem entre a 'fala' e a 'escrita' no Brasil, pois falávamos o brasileiro mas escrevíamos ainda em português. Seria necessário então ultrapassar e superar essa decalagem, inscrevendo decisivamente agora a voz brasileira em outra escrita. Disso se pode depreender como a crítica ao princípio nomológico do arquivo colonial orientava a leitura de Mário de Andrade, na refundação do arquivo da brasilidade, no que tange à sua problemática fundamental, qual seja, a da língua. Sem a referência a esta, na sua especificidade e singularidade, não seria possível constituir um arquivo da brasilidade centrado num pressuposto anticolonial.

Essa problemática já se encontrava presente, de maneira bem precoce, no percurso teórico de Mário de Andrade. Desde Paulicéia desvairada, com efeito, ele enunciava que o idioma brasileiro formou-se desde os primórdios do Brasil colonial, construindo assim uma tradição linguageira específica pela qual se produzia uma 'diferença' significativa em relação ao português, como matriz lingüística (Andrade, 1980a, p.28, 2002a, p.267-272). No entanto essa tradição linguageira foi constituída de maneira 'inconsciente', sem que os falantes brasileiros se dessem conta da diferença que já imprimiam na língua portuguesa, com suas inflexões e as singularidades de suas vozes.

Encontramos já na alusão à apropriação brasileira do português, pela diferença imprimida na produção de uma nova voz, uma primeira referência importante à psicanálise, no discurso de Mário de Andrade. Ele enuncia um processo brasileiro de recepção da língua portuguesa, em que esta foi transformada de maneira inconsciente pelos falantes.

Além disso, na decalagem entre os registros da voz e da escrita da língua brasileira em relação ao idioma português, a dimensão inconsciente da língua brasileira se enunciaria ainda de forma similar. Se a língua portuguesa foi constitutiva da tradição brasileira e do arquivo originário da brasilidade, sem dúvida a língua brasileira foi-se constituindo progressiva e inconscientemente, ao lado da primeira, pelas diferenças aos poucos produzidas. Dessa maneira, o arquivo da brasilidade se estaria constituindo desde os primórdios da colonização do Brasil, marcando de modo inconsciente a sua ruptura e descontinuidade diante do arquivo português e colonial. Enfim, a desconstrução da língua portuguesa pela brasileira estaria então já em pauta, construindo-se assim a leitura do mundo de outra maneira, já que orientada por outro olhar, delineado pela nova língua.

Como Mário de Andrade teorizou sobre isso? De maneira sugestiva e interessante, ele afirma que as línguas em geral 'precedem' efetivamente as suas gramáticas (Andrade, 1980a). Portanto, do ponto de vista tanto histórico quanto lógico, a língua como voz e fala precede a sua constituição e formalização no registro da gramática. Impõe-se aqui, na escrita de Mário de Andrade, a segunda referência à psicanálise e ao inconsciente, pois esse processo de constituição da língua se daria também de maneira inconsciente. Isso porque este, como estrutura fundamental do psiquismo, não conheceria as gramáticas nem as línguas organizadas. A lógica do inconsciente, enfim, seria diferente da lógica da consciência, que estaria no fundamento da constituição das diferentes gramáticas. 
Portanto, se o projeto teórico de Mário de Andrade era o de refundar o arquivo brasileiro com um fundamento nomológico anticolonial, o seu ponto de partida tinha que ser necessariamente a construção singular da língua brasileira, na sua diferença com a língua portuguesa, desde o início da colonização do país. Isso porque a construção do arquivo e da tradição da brasilidade foi realizada, desde os nossos primórdios, pela desconstrução efetiva da língua portuguesa realizada pela língua brasileira.

Nessa perspectiva o movimento modernista dos anos 20 foi a assunção plena, no registro da consciência estética, do arquivo da brasilidade, mas esse processo já se teria iniciado desde o Brasil colonial. Por isso mesmo a voz da brasilidade se efetivou inicialmente e se diferenciou em relação à escrita ainda portuguesa, que permaneceu como marca emblemática da tradição colonial. Porém outra escrita começou a forjar-se com a poética modernista, que passou a escrever em brasileiro, como realizou minuciosamente Mário de Andrade (1970) na disseminação das retóricas indígena e africana, ao lado da portuguesa, no seu romance intitulado Macunaíma.

\section{Loucura, primitividade e criação}

Para realizar então a desconstrução do arquivo fundado no princípio colonial de comando, em prol de um princípio nomológico centrado na brasilidade como tradição, seria necessário fazer 'trabalhar' a língua brasileira, fundamento do novo arquivo. Dessa maneira, os particularismos e os regionalismos folclóricos poderiam ser superados pelo novo arquivo, que passaria a delinear o Brasil como nação e como totalidade orgânica.

Como empreender isso? O intelectual brasileiro deveria assumir uma postura 'desvairada' em face das suas supostas representações erudita e européia, para que se pudesse curar da crônica e maldita 'moléstia de Nabuco'. Estou-me valendo aqui propositalmente do significante 'desvairado', pois foi justamente este que Mário de Andrade escolheu para intitular o seu primeiro livro de poesia: Paulicéia desvairada. No entanto, mais do que uma palavra lançada ao léu, o significante 'desvairado' pretende remeter a um 'método' de desconstrução do arquivo colonialista, com vistas a refundar o arquivo da brasilidade, como ainda se verá adiante.

Assim, teria sido pelo emblema simbólico do desvairismo que Mário de Andrade empreendeu o percurso inaugural da sua poética, uma vez que aquele emblema seria um princípio metódico 'negativo'. Por que negativo? Porque suas teorias seriam um 'disparate'. Ainda que elas não expliquem e não vallham 'coisíssima nenhuma', teriam a potência de desorganizar o arquivo brasileiro pré-modernista e possibilitar a constituição do arquivo da brasilidade, a começar pela sua proposição axiomática, qual seja, o enunciado de uma língua brasileira. Portanto, o dito desvairismo, mediado pelo disparate, seria o princípio metódico negativo que poderia realizar a desconstrução do arquivo colonialista brasileiro e abrir espaço retórico para a construção do arquivo da brasilidade propriamente dito.

Evidentemente a alusão ao desvairado remete à metáfora da 'loucura', considerada que foi, por Mário de Andrade, um signo marcado pela positividade e não pela negatividade. Com efeito, como para alguns dos modernistas, e principalmente Oswald de Andrade, nos seus manifestos - "Manifesto pau-brasil" (Andrade, 1972a) e "Manifesto antropófago" 
Joel Birman

(Andrade, 1972b) -, as figuras do 'primitivo' e do louco são positivadas como potências de 'vida' e de 'criação'. Não seriam então signos da decadência e da regressão biológica, social e simbólica, inseridos que estavam numa perspectiva teórica que já realizava a crítica sistemática do evolucionismo, no qual aquelas figuras seriam signos eloqüentes de involução e de degeneração.

A positividade presente na experiência da loucura implicaria o reconhecimento de que a experiência da criação pressupunha a destruição prévia de algo, numa rebeldia eminentemente criativa, o que remete tanto ao discurso romântico quanto ao discurso nietzschiano sobre o gênio. Foi nesse sentido, me parece, que Mário de Andrade (1980a), no prefácio de Paulicéia Desvairada, pôde referir-se a Olavo Bilac, para quem a destruição implicaria a criação. No que concerne ao primitivo, este seria a condensação 'virtual' de todas as possibilidades, metáfora por excelência que seria da 'potência' e da criação. Daí porque a figura do primitivo transformou-se numa das figuras heróicas do ideário modernista, tanto em Mário de Andrade quanto em Oswald de Andrade. Seria justamente pelo reconhecimento da positividade e da potência do primitivo, diante do europeu supostamente civilizado, que a constituição do arquivo da brasilidade seria possível, pois todas as potencialidades estariam então abertas para o futuro da tradição brasileira. A primitividade seria o grande trunfo para a constituição dessa tradição, pois todos os percursos seriam possíveis a partir dessa virtualidade potente.

No entanto a loucura e a primitividade estariam inscritas no registro psíquico do inconsciente, ao passo que a suposta civilização e a gramaticalidade que lhe seria correlata, no registro da consciência. Por isso mesmo, tal como a loucura e a primitividade, a criatividade poética seria também inconsciente. Em decorrência, a impulsão lírica e a inspiração poética seriam forjadas efetivamente no inconsciente (Andrade, 1980a, p.27). Apenas posteriormente a consciência reconheceria e diria algo sobre o que se produziu no ato poético, procurando justificar logicamente o que já teria efetivamente acontecido (Andrade, 1980b, p.13).

Foi justamente nesses termos que Mário de Andrade procurou articular a relação entre o conjunto de poemas que constituíram Paulicéia desvairada e o "Prefácio interessantíssimo", que é a sua introdução. O corpo poético da obra se constituiu primeiro de maneira inconsciente, como impulsão lírica, sem qualquer planificação racional, e apenas posteriormente, com os poemas escritos, a teorização sobre a obra foi então possível e escrita como prefácio.

O que implica dizer que a arte seria a afirmação da 'vida' como potência e linguagem, sem qualquer presunção da gramaticalidade e da lógica formal, e que se constituiria da mesma forma que o 'sonho'. A concepção de inconsciente se evidencia aqui novamente, com bastante clareza e literalidade, na escrita de Mário de Andrade. Pode-se depreender disso as referências tanto ao discurso psicanalítico de Freud (1976) e de Nietzsche (1977) quanto ao discurso estético do romantismo (Gusdorf, 1982, 1993), que delinearam a poética e a estética com tais cânones acima destacados. Portanto, a vida seria antes de mais nada 'poiesis' e sonho, a balbuciarem sua voz como linguagem, e o 'ser' poderia assim se afirmar como potência. Essa afirmação da vida como potência é o que nos levaria não apenas ao sonho, mas também ao riso e ao sofrimento (Andrade, 1980a) - o escárnio e a dor seriam 
modalidades outras de manifestação da vida e do inconsciente. Porém o pensamento crítico sobre essas experiências primordiais e primitivas se constituiria posteriormente, numa 'reflexão' sobre o que se produziu a princípio como 'poiesis', da mesma forma que a gramática e a língua formalizadas.

Nessa perspectiva, a impulsão lírica, amalgamada que seria com a matéria-prima da primitividade e da loucura como potências do inconsciente, seria de ordem "instintiva"; daí a sua "feiúra" e a sua marca eminentemente "escatológica" (Andrade, 1980a, p.19). Portanto o belo seria uma transformação desse magma originário, inicialmente mal-cheiroso, mal-educado e louco. Nesse aspecto, o que estaria em pauta seria a operação psíquica da 'sublimação' (Andrade, 1980a), mediante a qual a beleza seria a transmutação daquilo que seria originariamente feio e horroroso. Aqui, a referência teórica à psicanálise é também evidente. Ao aludir ao sonho e ao inconsciente, Mário de Andrade se refere a A interpretação dos sonhos, de Freud (1976), até mesmo porque a equação simbólica entre a loucura, o primitivo, o infantil e o inconsciente foi aqui formulada. Além disso, o que se enuncia então é uma referência explícita ao conceito de sexualidade infantil, forjada por Freud em Três ensaios sobre a teoria da sexualidade (Freud, 1962), pois a concepção de que a sublimação seria uma transformação do que originariamente é erótico, feio e horroroso é uma das teses apresentadas nessa obra constitutiva do discurso psicanalítico.

Referências teóricas à psicanálise continuam a pulular na escritura de Mário de Andrade sobre a poética. A problemática da linguagem foi retomada, num aprofundamento crucial. Sua outra tese sobre a poesia é que esta se deveria aproximar da 'música', que seria forjada no inconsciente (Andrade, 1980a, p.22-25). A música, com efeito, teria abandonado há muito a 'melodia' em nome da 'harmonia'. Retomando Wagner, Mário de Andrade afirma que a harmonia seria de ordem inconsciente e estaria portanto longe de qualquer gramaticalidade. Já a melodia seria a resultante de uma operação de imposição da gramática sobre uma harmonia originária, constitutiva do inconsciente. A linguagem seria então constituída por sonoridades harmoniosas e não melódicas, nas quais o inconsciente estaria plasmado como potência de vida, nas suas dimensões erótica, feia e escatológica. Seriam essas sonoridades que constituiriam a impulsão lírica, que teria então uma base eminentemente instintiva. Inscrito que estava nas tramas discursivas de Freud e Nietzsche (Wagner), Mário de Andrade forjava agora um conceito de linguagem e de poiesis que se fundaria nos instintos, pelos quais o inconsciente e a vida se amalgamariam como afirmação de potência do ser.

Em diferentes ensaios dos anos 60, Foucault (1994a, 1969) forjou o conceito de linguagem como 'murmúrio'. Assim, pela escrita as palavras e as frases viriam aos borbotões, sem ordenação lógica, reguladas apenas pelo 'acontecimento', que seria a sua condição de possibilidade. A concepção de linguagem como murmúrio pode ser perfeitamente aproximada da formulação que faz Mário de Andrade da linguagem como harmonia e não como melodia. Nesse particular, o que aproxima Foucault e Mário de Andrade é o discurso filosófico de Nietzsche.

Para concluir este tópico, é preciso ainda evocar as figuras do louco e do primitivo, agora no campo das artes plásticas. Numa crônica de 1929 centrada na leitura da obra de Cícero Dias, Mário de Andrade (2005d, p.111-112) enfatizou o estilo surrealista presente nas suas imagens pictóricas e destacou a proximidade da linguagem do surrealismo com as 
Joel Birman

do louco e do primitivo. Seria ainda a referência ao inconsciente que estaria aqui em pauta, de maneira decisiva, no registro da pintura. Enfim, Mário de Andrade estaria bastante distante do discurso do evolucionismo antropológico e da psiquiatria, no que concerne à loucura e ao primitivo, aproximando-se e valendo-se efetivamente dos conceitos freudianos.

\section{Inconsciente, fantasma e arquivo}

Se o que se disse até agora ficou claro e evidente, o discurso freudiano impregnou a retórica de Mário de Andrade, tanto para constituir a estética modernista quanto para conceber os conceitos de arquivo da brasilidade e de tradição brasileira.

Assim, os conceitos de Freud se impõem no "Prefácio interessantíssimo" de Paulicéia desvairada: subconsciente (Andrade, 1980a, p.17), censura (p.28), inconsciente (p.13), instinto (p.19), recalcamento sexual (p.18-19) e sublimação (p.19). Tudo isso foi enunciado para nos dizer que o discurso teórico sobre a arte e a literatura não se poderia fundar na tradição do racionalismo filosófico. Por esse viés os conceitos de inconsciente e instinto são entendidos como constituintes não apenas da linguagem, mas também da memória e do arquivo. É o que pretendo demonstrar agora, com um pouco mais de rigor, no que se refere aos registros do arquivo e da memória, articulando-os à concepção estética de Mário de Andrade pela mediação do conceito de inconsciente.

Mário de Andrade realizou sua leitura sobre a memória e o arquivo numa dupla mas complementar direção teórica. Na primeira, colocou-se em pauta a idéia de 'assombração', ao passo que na segunda estavam em questão as idéias de 'marca' e 'traço'.

Antes de mais nada, a memória e o arquivo se materializariam como assombração, de maneira que a ênfase aqui foi colocada na dimensão da ficção. O que implica dizer que se destaca o registro da imaginação e não o da sensorialidade. O que significa essa formulação, afinal das contas? É que a relação do sujeito com o mundo não se daria mais na direção classicamente estabelecida entre os pólos da sensorialidade e do entendimento, em que do primeiro se iria para o segundo registro. Uma inversão significante ocorreria, colocando em suspensão esse modelo cognitivo clássico (Andrade, 2005b).

Com efeito, seria agora o arquivo, permeado que é por traços e palavras, que passaria a encantar o mundo de maneira a produzir assombrações. O arquivo ficcionalizaria as relações do sujeito com o mundo pelas assombrações imaginativas, advindas dos traços e das palavras que lhes perpassariam. Evidentemente tal impregnação e disseminação encantatória do mundo pelas assombrações implica a existência de 'fantasmas' que estariam presentes no campo do arquivo. Se neste não existissem fantasmas, por que então falar em assombrações? Parece-me que isso é óbvio. Portanto, permeado que seria por fantasmas/assombrações, o arquivo se fundaria na imaginação, que como potência de ficção encantaria então o mundo.

$\mathrm{O}$ arquivo, assim, não seria constituído apenas por reminiscências estáticas, como ocorreria com o registro da memória, mas seria permeado por fantasmas que perpassariam os interstícios das reminiscências e nelas promoveriam até mesmo um certo dinamismo rítmico. Os fantasmas/assombrações se inscreveriam no corpo, assim como nos intervalos entre as palavras e as frases, conferindo outra ênfase, direção e acento nas relações do sujeito com o mundo que fundaria o campo da própria experiência. Porém, ao lado disso 
e em conjunção com isso, o arquivo seria também constituído como 'trilhas' e 'rastros' de signos, que se fariam presentes no espírito como sulcos impressos a delinear direções a serem percorridas.

Foi justamente essa concepção de arquivo que esteve presente na escrita de Mário de Andrade (2005c), quando ele se referiu aos passos do índio peruano Huitota, que tanto o encantaram: "Quando permito que o passado se lembre de mim, às vezes sinto esses pés Huitotas andando na minha memória. E à medida que o tempo me afasta deles, vai ficando cada vez mais passos e cada vez mais memórias... Se eu os posso identificar com a minha memória e só pelo que está neste papel é que os homens podem saber o que foram estes passos". O sujeito está aqui efetivamente 'descentrado' - "quando permito que o passado se lembre de mim" - diante da memória, evidenciando novamente em Mário de Andrade a suposição teórica do inconsciente freudiano. Ao lado disso, o objeto real se perde (o índio peruano, seu andar rápido) e no seu lugar ficam apenas as marcas de seus passos, como trilhas e rastros na memória, isto é, como signos que remetem à sua existência pretérita. Como 'ausência', no entanto, a existência coletiva desses passos não pode subsistir sem que sejam 'impressos' e 'inscritos' numa folha de papel pelo escritor, que os transmite. Portanto, diferentemente da memória, íntima e evanescente - ela pode ou não se lembrar de mim, numa temporalidade que é incontrolável no seu retorno e repetição -, o arquivo é o que permite que a memória seja inscrita como um conjunto de traços num dado 'suporte' (p.82-83), no caso a folha de papel.

Esse conjunto de traços que se imprime é construído como trilhas e rastros, marcados que são pela 'diferença' dos signos que se opõem. O que importa, na marcha rápida e vigorosa do índio peruano, é a maneira e a forma como impactaram o olhar e a experiência de Mário de Andrade, que os fixou inicialmente como marcas, numa 'ausência' do referente (o índio peruano) que viveu no passado. A evocação se realiza de maneira eminentemente ficcional, pela qual a ausência se torna presença fantasmática fugidia, pela via da assombração e da espectralidade (Andrade, 2005c). Seria essa 'escrita' psíquica que se imprime posteriormente no suporte do papel, na sua transmutação em discurso e texto que então se escreve. O que ressalta aqui é o modelo de psiquismo delineado por Freud (1976) no famoso capítulo VII de A interpretação dos sonhos. O que se passa no registro da consciência-percepção perde-se imediatamente e aparece depois como traço e signo, constituindo então o registro psíquico do inconsciente. É o psiquismo como arquivo e como sistema arquival o que se destaca, portanto, de maneira eloqüente. Os fantasmas, como espectros que nos perpassam de maneira permanente e insistente, seriam fulgurações que circulam nos interstícios desses traços e signos, aparecendo então como assombrações.

Para Freud o arquivo se ordena no registro do inconsciente, sendo forjado por traços e signos daquilo que se perdeu como presença e que se fixou como ausência. Pela mediação dos traços e signos a ausência pretende tornar-se novamente presença, com a circulação dos fantasmas como assombrações que se impõem a nós. Para Mário de Andrade, era essa matéria-prima arquivada no inconsciente que constituía a tradição brasileira propriamente dita, a qual, fundando-se na especificidade da língua brasileira na sua diferença com a língua portuguesa, nos possibilitaria alçar à posição de universalidade pela afirmação do que é singular na brasilidade. 
Joel Birman

Macunaíma foi o contraponto poético das pesquisas teóricas e críticas de Mário de Andrade sobre a tradição brasileira porque condensa, na sua escritura, a concepção da tradição forjada pelo autor não apenas na sua linguagem, que amalgama propositalmente os registros popular e erudito da brasilidade, mas também nas suas problemáticas, temas e reflexões. Com efeito, o personagem Macunaíma é o nosso herói sem nenhum caráter porque esqueceu a tradição e o arquivo da brasilidade, estando, pois, ainda adormecido como os demais brasileiros. Por isso mesmo, o percurso imaginário de Macunaíma seria o de realizar a descoberta do Brasil - como realizou, aliás, Mário de Andrade -, para sair de sua condição adormecida e despertar para a tradição da brasilidade.

Porém se o arquivo como conjunto de signos se atualiza no presente, por meio de assombrações e espectros, visando constituir o futuro como possibilidade efetiva, seria porque o registro da sensorialidade como percepção se encontra parcialmente obstruído pelo impacto do 'excesso', que se transforma inevitavelmente em trauma. Assim, se já precocemente, no seu "Prefácio interessantíssimo" a Paulicéia desvairada, Mário de Andrade (1980a, p.19-20) nos dizia que os sentidos eram frágeis, em "Táxi: memória e assombração" ele é ainda mais enfático em relação a isso quando afirma:

\begin{abstract}
na verdade o que a gente faz é povoar a inteligência de assombrações exageradas e secundariamente falsas. Esses sonhos de acordado, poderosamente revestidos de palavras, se projetam da inteligência pros sentidos e dos sentidos pro ambiente exterior, se alargando cada vez mais. São as assombrações. Diferentes pois das sensações, as quais do ambiente exterior pros sentidos e destes para a inteligência vêm se diminuindo cada vez mais. E essas assombrações por completo diferentes de tudo quanto passou é que a gente chama de "passado" (Andrade, 2005b, p.83; grifos meus).
\end{abstract}

É possível aproximar essa leitura arguta de Mário de Andrade, sobre a recente modernidade brasileira, daquela realizada por Benjamin (2000b, p.387-390) sobre a poesia de Baudelaire e o impacto traumático da modernidade sobre a experiência social e o discurso poético. Benjamin procurou delinear as novas condições do arquivo na modernidade valendo-se do ensaio de Freud (1981) sobre o traumático, a repetição e a pulsão de morte, intitulado Além do princípio do prazer. Nesse contexto, a figura poética do 'narrador' se faz então impossível (Benjamin, 2000a), e a poesia moderna tem que ser construída a partir de tais restos traumáticos, para procurar dar sentido à experiência social agora fragmentária.

Portanto, em Mário de Andrade a modernidade brasileira seria então impactante, tornando frágeis os nossos sentidos. Para contornar esse obstáculo, necessário seria então acordar e despertar nossos espectros e fantasmas, para encantarmos o mundo e a experiência social com as trilhas e assombrações dos arquivos da brasilidade e realizarmos assim a construção da nossa tradição a partir dos signos marcados no inconsciente. Com isso poderíamos ter um futuro possível, retomando as nossas marcas arquivais para nos direcionar ficcionalmente na fragmentação presente na atualidade. Foi isso que o modernismo, como movimento do despertar brasileiro, tentou realizar na Semana de 1922, da qual Mário de Andrade foi um dos mais importantes arautos. Foi isso ainda que ele procurou realizar pela retomada dos arquivos (inconscientes) da brasilidade. Por isso tudo, se ele tem que ser arquivado como um dos rapsodos e como um patrimônio simbólico da tradição da brasilidade, não se pode esquecer sua lição e sabedoria maior, qual seja, a de que o arquivo não é 'fato' e tampouco 
'documento' a ser embalsamado como 'monumento', mas sim uma construção sempre móvel e plástica, que se tece na relação viva da atualidade com o futuro e com o passado. Somente assim o arquivo poderia ser perpassado efetivamente pela historicidade e ser matéria-prima e condição de possibilidade da genealogia de uma tradição.

\section{NOTA}

* Este artigo resulta das notas que me orientaram na intervenção realizada na Casa de Oswaldo Cruz/ Fiocruz (RJ), na Semana do Patrimônio Fiocruz, na mesa-redeonda Cultura, Identidade e Patrimônio em Maário de Andrade, em 22 de maio de 2007.

\section{REFERÊNCIAS}

ANDRADE, Mário.

Ensaio sobre a música brasileira. Belo Horizonte: Itatiaia, 2006

ANDRADE, Mário.

Táxi: casa de pensão. In: Andrade, Mário.

Táxi e crônicas no Diário Nacional. Belo

Horizonte: Itatiaia. p.66. 2005a.

ANDRADE, Mário.

Táxi: memória e assombração. In: Andrade, Mário. Táxi e crônicas no Diário Nacional. Belo Horizonte: Itatiaia. p.82-83. 2005b.

ANDRADE, Mário.

Táxi: 'de-a-pé'. In: Andrade, Mário. Táxi e crônicas no Diário Nacional. Belo Horizonte: Itatiaia. p.147-148. 2005c

ANDRADE, Mário.

Cícero Dias. In: Andrade, Mário. Táxi e crônicas no Diário Nacional. Belo Horizonte: Itatiaia. p.111-112. 2005d.

ANDRADE, Mário.

O movimento modernista. In: Andrade, Mário. Aspectos da literatura brasileira. 6.ed. Belo Horizonte: Itatiaia. p.266-276. 2002a.

ANDRADE, Mário.

A elegia de abril. In: Andrade, Mário. Aspectos da literatura brasileira. 6.ed. Belo Horizonte: Itatiaia. 2002b.

ANDRADE, Mário.

Dicionário musical brasileiro. Belo Horizonte: Itatiaia, 1999.

ANDRADE, Mário.

Aspectos da música brasileira. Rio de Janeiro: Vila Rica. 1991.

ANDRADE, Mário.

Prefácio interessantíssimo [a Paulicéia desvairada]. In: Andrade, Mário. Poesias completas. Belo Horizonte: Itatiaia. p.17-31. 1980a.

ANDRADE, Mário.

Descobrimento (Dois poemas acreanos).
In: Andrade, Mário. Poesias completas. Belo Horizonte: Itatiaia. 1980b.

ANDRADE, Mário.

O turista aprendiz. São Paulo: Duas Cidades. 1976.

ANDRADE, Mário.

O artista e o artesão. In: Andrade, Mário.

O baile das quatro artes. São Paulo: Livraria

Martins Editora. 1975.

ANDRADE, Mário.

Macunaíma: o herói sem nenhum caráter. 6.ed. São Paulo: Martins. 1970.

ANDRADE, Oswald.

Manifesto da poesia pau-brasil. In: Andrade, Mário. Do pau-brasil à antropofagia e às utopias. Rio de Janeiro: Civilização Brasileira; MEC. (Obras Completas, 6). 1972a.

ANDRADE, Oswald.

Manifesto antropófago. In: Andrade, Mário. Do pau-brasil à antropofagia e às utopias.

Rio de Janeiro: Civilização Brasileira; MEC. (Obras Completas, 6). 1.ed., 1928. 1972b.

BENJAMIN, Walter.

Passagens. Belo Horizonte: UFMG; Imprensa Oficial do Estado de São Paulo. 2006.

BENJAMIN, Walter.

Le conteur. In: Benjamin, Walter. Oeuvres III. Paris: Gallimard. 2000a.

BENJAMIN, Walter.

Sur quelques thèmes baudelairiens. In: Benjamin, Walter. Oeuvres III. Paris: Gallimard. p.387-390. Folio. 2000b.

BENJAMIN, Walter.

Sur le concept d’histoire. In: Benjamin, Walter. Écrits français. Paris: Gallimard. 1991.

BERNS, Thomas.

Violence de la loi à la Renaissance: l'originaire du politique chez Machiavel et Montaigne. Paris: Koiré. 2000. 
Joel Birman

BRAUDEL, Fernand.

Écrits sur l'histoire. 2. parte. Paris: Flammarion. 1969.

DEJEAN, Joan.

Ancients against moderns. Chicago:

The University of Chicago Press. 1997.

DERRIDA, Jacques.

Mal d'archive: une impression freudienne. Paris: Galilée. 1995.

DERRIDA, Jacques.

L'écriture et la différence. Paris: Seuil. 1967a.

DERRIDA, Jacques.

De la grammatologie. Paris: Minuit. 1967b.

DERRIDA, Jacques; FOUCAULT, Michel.

Três tempos sobre A História da Loucura.

Rio de Janeiro: Relume-Dumará. 2001.

ETIENNE FILHO, João.

Poeta completo. In: Andrade, Mário. Poesias completas. v.1. 6.ed. Belo Horizonte: Itatiaia. p.1. 1980 .

FOUCAULT, Michel.

Distance, aspect, origine. In: Foucault, Michel. Dits et écrits. v.1. Paris: Gallimard. 1.ed., 1963. 1994a.

FOUCAULT, Michel.

Le langage à l'infini. In: Foucault, Michel. Dits et écrits. v.1. Paris: Editions Gallimard. 1994b.

FOUCAULT, Michel.

Qu'est-ce qu'un auteur. In: Foucault, Michel.

Dits et écrits. v.1. Paris: Gallimard. 1.ed., 1969. 1994c.

FOUCAULT, Michel.

Nietzsche, la généalogie, l'histoire. In: Foucault, Michel. Dits et écrits. v.2. Paris: Gallimard. 1.ed. 1971. 1994d.

FOUCAULT, Michel.

Les techniques de soi. In: Foucault, Michel. Dits et écrits. v.4. Paris: Gallimard. 1.ed., 1988. 1994e.

FOUCAULT, Michel.

L'archéologie du savoir. Paris: Gallimard. 1969.

FREUD, Sigmund.

Au-de là du principe du plaisir. In: Freud,

Sigmund. Essais de psychanalyse. Paris: Payot.

1.ed., 1920. 1981.

FREUD, Sigmund.

L'interprétation des rêves. Paris: PUF. 1.ed., 1900. 1976.

FREUD, Sigmund.

Trois essais sur la théorie de la sexualité. Paris: Gallimard. 1.ed., 1905. 1962.

GAGNEBIM, Jeanne Marie.

História e narração em W. Benjamin. São Paulo: Perspectiva. 1994.
GUSDORF, Georges.

Le romantisme. v.1, 2. Paris: Payot. 1982, 1993.

JAUSS, Hans Robert.

Pour une esthétique de la recéption. Paris: Gallimard. 1978.

JARDIM DE MORAES, Eduardo.

Mário de Andrade: a morte do poeta. 1.ed.

Rio de Janeiro: Civilização Brasileira. 2005.

JARDIM DE MORAES, Eduardo.

A brasilidade modernista: sua dimensão

filosófica. 1.ed. Rio de Janeiro: Graal. 1978.

KOYRÉ, Alexandre.

Du monde clos à l'univers infini. Paris: Gallimard.

1973.

LECOQ, Anne-Marie.

La querelle des anciens et des modernes. Paris:

Gallimard. (Folio Classique). 2001.

LEFORT, Claude.

Le travail de l'oeuvre: Machiavel. Paris:

Gallimard. 1972.

MACHIAVEL, Nicolas.

Discours sur la première décade de Tite-Live.

In: Machiavel, Nicolas. Oeuvres complètes. Paris: Gallimard. (Plèiade). 1952a.

MACHIAVEL, Nicolas.

Le Prince. In: Machiavel, Nicolas. Oeuvres complètes. Paris: Gallimard. (Plèiade). 1952b.

NEVES, Margarida de Souza.

Da Maloca do Tietê ao Império do Mato Virgem: Mário de Andrade, roteiros e descobrimentos. In: Chalhoub, Sidney. e Pereira, Leonardo A.M. (Org). A história contada: capítulos da história social da literatura do Brasil. Rio de Janeiro: Nova Fronteira. 1998.

NIETZSCHE, Friedrich.

Seconde considération intempestive: de l'utilité et de l'incovénient des études historiques pour la vie. Paris: Flammarion. 1.ed., 1874. 1988.

NIETZSCHE, Friedrich.

La naissance de la tragédie. Paris: Gallimard. 1977.

NIETZSCHE, Friedrich.

La généalogie de la morale. Paris: Gallimard. 1971.

Plutarque

Vies parallèles. Paris: Gallimard. 2001.

SKINNER, Quentin.

Machiavelli. Oxford: Oxford University Press.

1981.

STRAUSS, Lévis.

La cité et l’homme. Paris: Agora. 1987.

STRAUSS, Lévis.

Droit naturel et histoire. Paris: Flammarion. 1986.

VOEGELIN, Eric

La nouvelle science politique. Paris: Seuil. 2000. 